\title{
APLIKASI MOBILE SCOTECT: APLIKASI DETEKSI WARNA TANAH DENGAN TEKNOLOGI CITRA DIGITAL PADA ANDROID
}

\author{
Ihwanudien Hasan Robbani ${ }^{1}$, Enny Trisnawati ${ }^{2}$, Rakhmadina Noviyanti ${ }^{3}$, Afrizal Rivaldi ${ }^{4}$, Fadhilla Puji \\ Cahyani $^{5}$, Fitri Utaminingrum ${ }^{6}$ \\ ${ }^{123456}$ Program Studi Informatika, Universitas Brawijaya \\ Email: ${ }^{1}$ matno.robbani@gmail.ac.id, ${ }^{2}$ ennytrisna2207@gmail.com, ${ }^{3}$ rakhmadina11@gmail.com, \\ 4fadhillapuji@gmail.com, 5 afrizal.rivaldi17@gmail.com, ${ }^{6} \mathrm{f} 3$ _ningrum@yahoo.com
}

(Naskah masuk: 18 Februari 2016, diterima untuk diterbitkan: 17 Maret 2016)

\begin{abstract}
Abstrak
Salah satu komponen utama dari lahan adalah tanah. Untuk mengetahui tingkat kesuburan tanah, kita harus mengetahui bagaimana karakteristik tanah dari tanah. Untuk mengetahui bagaimana karakteristik tanah, cara yang paling mudah untuk dilakukan adalah dengan mengamati warna dari tanah tersebut. Jika kita amati, warna tanah di setiap lokasi dan kedalaman akan berbeda. Ada tanah berwarna hitam, coklat, merah, kuning, dan masih banyak lagi variasi warna tanah yang lain. Banyaknya variasi warna tanah membuat peneliti kesulitan dalam menentukan warna tanah, karena satu-satunya cara yang saat ini digunakan peneliti untuk menentukan warna tanah adalah dengan membandingkan secara manual satu persatu sampel yang dimiliki dengan warna baku yang ada pada buku Munsell Soil Color Chart. Variasi warna pada yang mencapai lebih dari 250 macam warna membuat peneliti membutuhkan waktu lama dan ketelitian dalam penentuan warna tanah. Untuk memecahkan permasalahan tersebut penulis menggagas sebuah alat bersifat mobile yang dapat membantu para peneliti di bidang ilmu tanah dalam menentukan warna lapisan tanah dengan nama SCOTECT (Soil Color Detection). SCOTECT merupakan aplikasi pada perangkat smartphone dengan OS Android, yang didalamnya telah ditanamkan algoritma dengan nama Algoritma SCOTECT yang merupakan sekumpulan tahapan proses yang digunakan untuk klasifikasi warna tanah. Smartphone dengan OS Android dipilih karena saat ini Android merupakan OS dengan perkembangan pengguna paling cepat dibandingkan OS yang lain. Dari hasil uji coba terhadap SCOTECT Mobile Apps didapatkan kesimpulan bahwa kinerja algoritma yang ditanamkan dalam aplikasi dapat melakukan klasifikasi warna tanah dengan akurasi sampai dengan 90,58\%. Dengan kata lain kedepan aplikasi ini dapat membantu peneliti dalam proses klasifikasi warna tanah.
\end{abstract}

Kata kunci: tanah, warna tanah, deteksi warna, mobile apps, SCOTECT

\begin{abstract}
Soil is a major component of the land. To determine the level of soil fertility, we must know how the soil characteristics. To find out how the characteristics of the soil, the color is the main characteristic of the most easily observed. Soil color varies greatly, ranging from jet black, brown, brick red, orange, yellow, to white. The great variation in color of the soil researcher difficulties in determining the color of the soil, because investigators must compare them manually one by one with a standard color on the Munsell Soil Color Chart book. Color variations on that reaches more than 250 kinds of colors make the researcher takes a long time and accuracy in the classification of the soil color. To solve these problems is the author initiated a mobile tool that could help researchers in the field of soil science in determining the color of the soil layer with the name SCOTECT (Soil Color Detection). SCOTECT is an application on smartphones with Android OS, which also have been implanted with the name algorithm SCOTECT algorithm which is a set of process steps used for the classification of soil color. Smartphone with Android OS have been selected for the current Android is an OS with the development of the fastest compared to other OS. From the test results against SCOTECT Mobile Apps was concluded that the performance of the algorithm is embedded in the application can perform color classification of land with an accuracy up to $90.58 \%$. In other words, the future of these applications can help researchers in the classification process color of the soil.
\end{abstract}

Keywords: soil, soil color, color detection, mobile apps, SCOTECT

\section{PENDAHULUAN}

Indonesia disebut sebagai negara agraris, hal ini dikarenakan memang sebagian besar penduduk memiliki profesi yang berkaitan dengan bidang pertanian. Banyaknya profesi yang berkaitan dengan bidang pertanian tidak akan terjadi jika tidak didukung oleh keadaan geografis dan luas lahan di Indonesia. Luas lahan di Indonesia pada tahun 2012 masih mencapai 39.594.536,91 Ha, lahan tersebut berdasarkan penggunaannya dikelompokkan menjadi sawah, tegal/kebun, ladang/huma, dan lahan yang sementara tidak digunakan (PUSAT DATA DAN SISTEM INFORMASI PERTANIAN, 2013). Luasnya lahan yang terbentang dari Sabang sampai 
Merauke, yang tentunya memiliki keadaan geografis, iklim, cuaca dan banyak faktor lain yang berbeda membuat kualitas setiap lahan di Indonesia juga berbeda.

Salah satu komponen dari lahan yang merupakan komponen utama adalah tanah (HARDJOWIGENO, 1992). Tanah merupakan salah satu komponen alami yang terdiri dari padatan (dapat berupa mineral dan/atau meteri organik), cairan, dan gas yang membentuk permukaan dari lahan, daerah lapang, dan dikarakteristikkan berdasarkan: lapisan, materi yang dilepaskan, materi yang dikirimkan, dan materi yang dirubah dari energi dan diukur berdasarkan kemampuannya mendukung pertumbuhan tumbuhan dalam lingkungan alami (UNITED STATES DEPARTMENT OF AGRICULTURE, 1999). Dapat atau tidaknya sebuah lahan digunakan bergantung pada kualitas tanah yang ada di lahan tersebut. Secara umum semakin bagus kualitas tanah (semakin subur tanah), tentu semakin bagus pula hasil yang didapatkan dari pengolahan atau penggunaan tanah tersebut.

Untuk mengetahui seberapa berkualitas tanah atau tingkat kesuburan tanah, kita harus mengetahui bagaimana karakteristik tanah yang ada di wilayah tersebut. Untuk mengetahui bagaimana karakteristik tanah, cara yang paling mudah untuk dilakukan adalah dengan mengamati warna dari tanah tersebut. Jika kita amati, warna tanah di setiap lokasi dan kedalaman akan berbeda. Ada tanah berwarna hitam, coklat, merah, kuning, dan masih banyak lagi variasi warna tanah yang lain. Tanah juga terdiri dari beberapa lapisan, dimana setiap lapisannya memiliki perbedaan warna yang bisa sangat bisa diamati, dan terkadang tidak mudah untuk diamati. Pebedaan ini diakibatkan oleh proses kimia (pengasaman) atau pencucian (leaching). Terkadang karakteristik tanah yang lain dapat diketahui dari warna tanah, seperti misalnya tanah yang berwarna hitam (gelap) biasanya menunjukkan kandungan bahan organik dalam tanah tersebut cukup tinggi. Selain bahan organik, kandungan beberapa zat kimia seperti contohnya mangan, belerang, dan nitrogen juga dapat menyebabkan warna tanah menjadi cenderung gelap. Contoh yang lain adalah tanah dengan warna kemerahan atau kekuningan. Tanah dengan warna kemerahan atau kekuningan dikareakan terdapat kandungan zat kimia besi teroksidasi yang tinggi. Selain disebabkan oleh zat yang terkandung di dalam tanah, ada hal lain yang mempengaruhi warna tanah yaitu kondisinya. Saat tanah basah, lembab, atau kering warnanya akan berbeda. (UNITED STATES DEPARTMENT OF AGRICULTURE, 2000)

Banyaknya variasi warna tanah membuat peneliti kesulitan dalam menentukan warna tanah, karena satu-satunya cara yang saat ini digunakan peneliti untuk menentukan warna tanah adalah dengan membandingkan secara manual satu persatu sampel yang dimiliki dengan warna baku yang ada pada buku Munsell Soil Color Chart. Variasi warna pada yang mencapai lebih dari 250 macam warna membuat peneliti membutuhkan waktu lama dan ketelitian dalam penentuan warna tanah. Selain itu bisa juga kondisi dari peneliti mempengaruhi kesimpulan yang dibuat.

Dalam rangka membantu dalam proses klasifikasi warna tanah, ada beberapa penelitian yang sebelumnya telah dilakukan oleh beberaporang peneliti. Salah satunya adalah pembuatan alat penentu warna tanah dengan memanfaatkan sensor TCS3200 sebagai pendeteksi warna yang telah dikonversi menjadi frekuensi (ANAM, 2015). Alat ini dianggap kurang efisien karena masih harus menggunakan alat baru yang digunakan, sehingga masih ada keterbatasan yang ditimbulkan dari penggunaan alat ini. Dalam penelitian lain juga telah dibuat sebuah aplikasi berbasis android yang digunakan untuk deteksi warna tanah dengan menggunakan histogram ruang citra HVC dengan klasifikasi KNN (PRIANDANA et al., 2014). Penelitian tersebut telah berhasil mengimplementasikan metode ekstraksi fitur histogram warna untuk masing-masing komponen warna pada model warna RGB dan HVC. Pada penelitian tersbut, klasifikasi warna tanah telah diimplementasikan dengan KNN untuk komponen warna hue. Hasil akurasi rata-rata tertinggi pada kelompok warna hue mencapai $45 \%$. Akurasi yang rendah ini menandakan bahwa masih perlu dikembangkan aplikasi berbasis mobile yang dapat digunakan melakukan deteksi warna tanah.

Karena masih sangat minimnya alat yang dapat membantu dalam penentuan warna tanah, penulis selanjutnya menggagas sebuah alat bersifat mobile yang akan dapat membantu para peneliti di bidang ilmu tanah dalam menentukan warna tanah. Aplikasi ini kemudian diberi nama SCOTECT (Soil Color Detection) Mobile Apps. SCOTECT merupakan sebuah aplikasi yang akan tertanam dalam smartphone dengan OS Android. Smartphone dipilih karena banyaknya fitur yang telah tersedia di dalamnya dimana salah satunya adalah kamera yang akan digunakan sebagai komponen utama pada SCOTECT. Sedangkan OS Android dipilih karena saat ini Android merupakan OS dengan perkembangan pengguna paling cepat dibandingkan OS yang lain selain juga karena kemudahan dalam pengembangan aplikasi pada OS Android. Menurut data yang dikeluarkan oleh International Data Corporation pada tahun 2012, OS Android menguasai sekitar $52 \%$ dari total smartphone yang dipakai oleh masyarakat Indonesia (WAHYUDI, 2012).

Dengan adanya Aplikasi Mobile SCOTECT diharapkan penentuan warna tanah akan dapat dilakukan dengan lebih mudah, cepat, dengan hasil yang lebih akurat sehingga akan berpengaruh secara signifikan terhadap kinerja para peneliti di bidang 
ilmu tanah. Selanjutnya diharapkan ini akan berpengaruh terhadap meningkatnya kualitas hasil pertanian di Indonesia dan juga meningkatnya kemajuan teknologi pertanian di Indonesia.

\section{STUDI PUSTAKA}

\subsection{Tanah}

Tanah merupakan benda alami yang terdapat di permukaan bumi, yang menjadi tempat hidup bagi semua makhluk hidup, termasuk menjadi media hidup bagi tumbuhan. (YULIPRIYANTO, 2010) Tanah didefinisikan sebagai salah satu komponen alami yang terdiri dari padatan (dapat berupa mineral dan/atau meteri organik), cairan, dan gas yang membentuk permukaan dari lahan, daerah lapang, dan dikarakteristikkan berdasarkan: lapisan, materi yang dilepaskan, materi yang dikirimkan, dan materi yang dirubah dari energi dan diukur berdasarkan kemampuannya mendukung pertumbuhan tumbuhan dalam lingkungan alami

\section{(UNITED STATES} AGRICULTURE, 1999).

\subsection{Warna Tanah}

Beberapa parameter digunakan untuk mengidentifikasi lapisan tanah, parameter-parameter tersebut diantaranya adalah warna, tekstur, struktur, dan konsistensi tanah (UNITED STATES DEPARTMENT OF AGRICULTURE, 2000). Satusatunya cara yang saat ini digunakan peneliti untuk menentukan warna tanah adalah dengan membandingkan secara manual satu persatu sampel yang dimiliki dengan warna baku yang ada pada buku Munsell Soil Color Chart. Warna tanah dipengaruhi oleh kandungan yang ada di dalam tanah, selain itu saat kondisinya lembab, basah, atau kering warna tanah juga akan berbeda. (UNITED STATES DEPARTMENT OF AGRICULTURE, 2000). Berikut kandungan mineral dan kecenderungan warna tanah pada Tabel 1.

Tabel 1. Kandungan Mineral dan Kecendurangan Warna Tanah

\begin{tabular}{ccc}
\hline mineral & munsell & warna \\
\hline goethite & 10YR 8/6 & kuning \\
\hline goethite & 7.5YR 5/6 & coklat yang kuat \\
\hline biji besi & 5R 3/6 & merah \\
\hline biji besi & 10R 4/8 & merah \\
\hline lepidocrocite & 5YR 6/8 & kemerahan kuning \\
\hline lepidocrocite & 2.5YR 4/6 & merah \\
\hline ferihidrit & 2.5YR 3/6 & merah gelap \\
\hline glauconite & 5Y 5/1 & abu-abu gelap \\
\hline besi sulfida & 10YR 2/1 & hitam \\
\hline pirit & 10YR 2/1 & hitam (logam) \\
\hline jarosit & 5Y 6/4 & kuning pucat \\
\hline todorokite & 10YR 2/1 & hitam \\
\hline humus & 10YR 2/1 & hitam \\
\hline kalsit & 10YR 8/2 & putih \\
\hline dolomit & 10YR 8/2 & putih \\
\hline gips & 10YR 8/3 & coklat sangat pucat \\
\hline kuarsa & 10YR 6/1 & abu-abu muda \\
\hline
\end{tabular}

Sumber: (UNITED STATES DEPARTMENT OF AGRICULTURE, 2000)

Dalam penentuan warna tanah menggunakan buku Munsell Soil Color Chart, ada beberapa hal dari warna yang menjadi perhatian, diantaranya (MUNSEL, 2009):

1. Hue: panjang gelombang dominan. Terdapat tiga macam yaitu Y (yellow), R (red), YR (yellow red).

2. Value: kecerahan cahaya jika dibandingkan dengan warna putih. Kisaran nilainya 0-10.

3. Chroma: kecerahan cahaya jika dibandingkan dengan warna putih. Kisaran nilainya 0-10.

\subsection{Computer Vision}

Computer vision merupakan proses otomatis yang mengintegrasikan sejumlah besar proses untuk beberapa persepsi visual, diantaranya adalah akuisisi citra, pengolahan citra, klasifikasi, pengenalan (recognition), dan membuat keputusan (MUNIR,
2004). Dalam pengolahan citra biasanya proses terdiri dari dua tahapan yaitu preprocessing, dan proses interpretasi citra. Dalam komputasi computer vision, proses yang biasa terjadi adalah:

1. Akuisisi citra digital.

2. Modifikasi data citra, yang lebih dikenal dengan operasi-operasi pengolahan citra.

3. Analisis dan interpretasi citra, dimana hasilnya digunakan untuk proses otomatis seperti memandu arah gerak dan perilaku robot, mengontrol kerja peralatan, memantau proses manufaktur, dan lain-lain.

\subsection{Citra Digital}

Citra digital memegang peranan sangat penting sebagai bentuk informasi visual (MUNIR, 2004). Citra digital merupakan sebuah larik (array) yang berisi nilai-nilai real maupun komplek yang 
direpresentasikan dengan deretan bit tertentu (PUTRA, 2010). Citra berbeda dengan data teks karena citra digital yang memiliki berbagai macam bentuk kaya akan informasi (MUNIR, 2004). Citra yang merupakan keluaran dari proses merekam dapat memiliki berbagai macam bentuk, diantaranya (MURNI, 1992):

1. foto (optik),

2. video (analog),

3. digital (disimpan pada suatu pita magnetik).

\subsection{Median Filter}

Median filter merupakan metode filter nonlinear. Keuntungan menggunakan median filter jika dibandingkan dengan metode filter linear adalah median filter dapat menghilangkan noise (derau) dalam ukuran yang lebih besar (PATIDAR et al., 2010). Median filter menggunakan ketetanggan dalam proses filternya, dan ukuran dari ketetanggan ditentukan dalam satu variabel tertentu. Jika terdapat sebuah citra dengan nilai piksel $X_{i j}$, dan akan dicari filter dari citra tersebut dengan menggunakan median filter maka fungsi untuk menghasilkan keluarannya didefinsikan dalam Persamaan (1), dimana $(s, t)$ merepresentasikan posisi dari piksel saat ini dan $w$ merepresentasikan ketetanggan dari piksel posisi saat ini (GONZALES \& WOODS, 2012).

$$
Y_{i j}=\operatorname{median}\left\{X_{i \pm s, j \pm r} \mid(s, t) \in w\right\}
$$

\subsection{K-Means}

Algoritma K-Means (KM) merupakan algoritma yang akan mengelompokkan data ke dalam sejumlah $k$ kelompok data. Fungsi keanggotaannya bergantung pada nilai kedekatan data dengan pusat kelompok yang telah ditentukan (HAMERLY \& ELKAN, 2002). Algoritma ini populer karena mudah dipahami dan mudah untuk diimplementasikan. Tahapan dari algoritma KM adalah (RAHMANI et al., 2014):

1. Inisialisasi sejumlah $k$ kelompok (cluster).

2. Menentukan pusat kelompok secara acak sejumlah $k$ kelompok yang telah ditentukan.

3. Menentukan keanggotaan data berdasarkan kedekatan terhadap setiap pusat kelompok, jarak yang paling dekat menunjukkan data tersebut merupakan anggota dari kelompok.

4. Menghitung pusat kelompok baru sesuai dengan hasil pengelompokkan yang telah dilakukan.

5. Mengulangi langkah 2 sampai dengan 4 sampai tidak ada perubahan pusat kelompok atau anggota kelompok.

\subsection{Euclidean Distance}

Euclidean distance merupakan metode yang sangat sering digunakan dalam proses deteksi kemiripan suatu objek. Untuk dua buah data dalam ruang berdimensi $\mathrm{p}$, misalkan $\mathrm{a}=(\mathrm{a} 1, \mathrm{a} 2, \ldots$, ap $)$ dan $\mathrm{b}=(\mathrm{b} 1, \mathrm{~b} 2, \ldots$. bp). Euclidean Distance antara a dan $\mathrm{b}$ didefinisikan sebagai persamaan (2) (DEZA \& DEZA, 2009).

$$
d_{e u c}(a, b)=\left[\sum_{j=1}^{p}\left(a_{j}-b_{j}\right)^{2}\right]^{\frac{1}{2}}
$$

\subsection{Android}

Android adalah sistem operasi yang dibuat oleh Google yang awalnya ditujukan untuk perangkat telepon pintar dan tablet. Android bersifat open source, yang artinya adalah kode sumbernya terbuka dan dapat dikembangkan oleh siapapun. Google merilis kode sumber Android dibawah Lisensi Apache. Didukung oleh sifat open source-nya, Android berkembang sangat pesat dan dalam perkembangannya memiliki banyak komunitas pengembang aplikasi.

\section{METODE}

\subsection{Data}

Dalam penelitian pengembangan Aplikasi Mobile untuk deteksi warna tanah data yang digunakan adalah citra yang diambil dari buku Munsel Soil Color Chart sebagai data latih dan sebagai data uji.

\subsection{Tahapan Penelitian}

Dalam melakukan penelitian pembuatan aplikasi untuk deteksi warna tanah ada beberapa tahapan proses yang dilakukan. Tahapan proses penelitian yang dilakukan adalah:

1. Desain tampilan

Desain user interface dilakukan untuk dapat menghasilkan aplikasi mobile yang mudah dan nyaman digunakan oleh pengguna SCOTECT Mobile Apps.

2. Implementasi Algoritma SCOTECT

Algoritma SCOTECT merupakan algoritma yang digunakan dalam proses deteksi warna. Algoritma SCOTECT terdiri dari beberapa tahapan proses algoritma. Tahapan dari Algoritma SCOTECT dalam proses deteksi warna tanah sesuai dengan yang ada Gambar 1 .

3. Evaluasi

Evaluasi hasil klasifikasi dapat dilakukan dengan cara menghitung tingkat akurasi menggunakan rumus sebagai berikut:

$$
\text { akurasi }=\frac{\sum \text { hasil prediksi benar }}{\sum \text { data uji keseluruhan }} \times 100 \%
$$




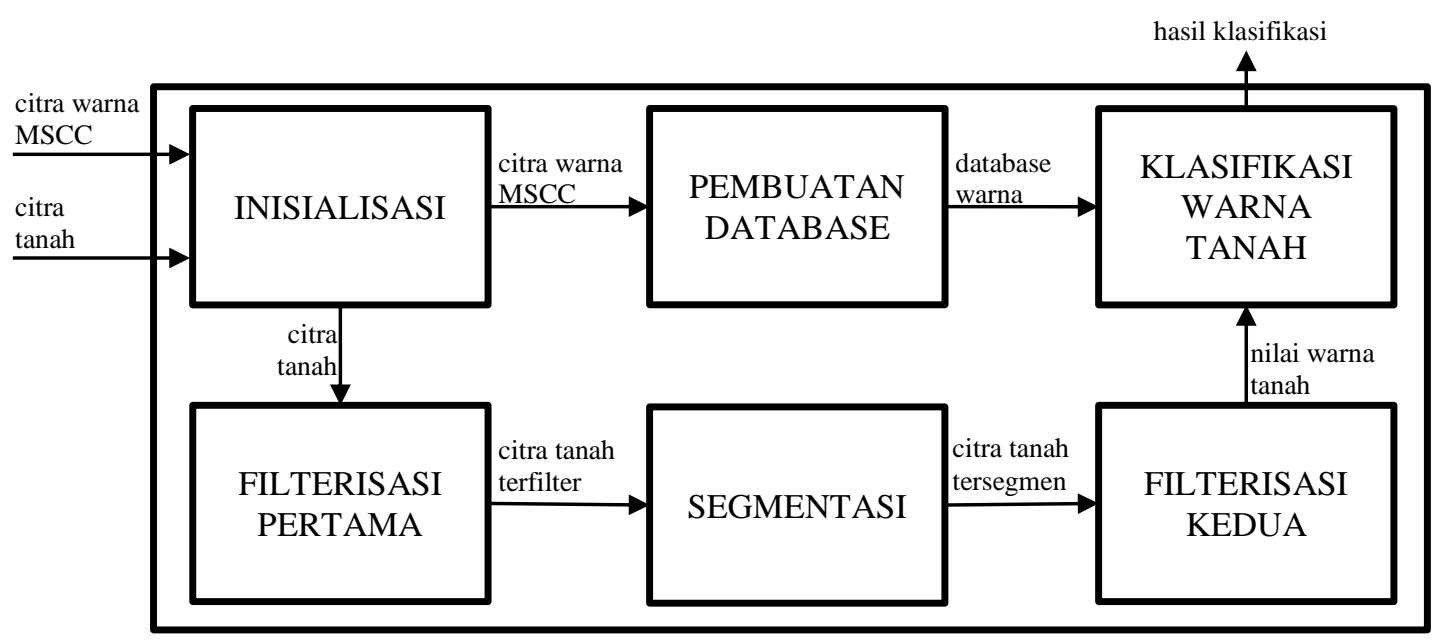

Gambar 1. Tahapan Proses Algoritma SCOTECT

\section{HASIL DAN PEMBAHASAN}

Aplikasi ini dibangun dengan menggunakan telepon genggam berbasis Android dengan spesifikasi pada Tabel 2. Dalam pembuatan desain aplikasi, desain tampilan aplikasi ini dibuat semudah mungkin agar pemakai bisa mudah memahami dalam penggunaan. Pembuatan aplikasi ini, menggunakan Aplikasi Android Studio sebagai alat bantu dalam pembuatan aplikasi.

Dalam proses akuisisi citra menggunakan SCOTECT Mobile Apps dapat dilakukan melalui dua cara yaitu mengambil citra digital tanah secara langsung menggunakan kamera dan/atau mengambil gambar dari data yang sudah ada dalam galeri. Kemudian aplikasi ini akan melakukan klasifikasi warna tanah dengan menggunakan Algoritma SCOTECT yang ada.

Tabel 2. Spesifikasi Perangkat

\begin{tabular}{|l|l|}
\hline Tipe HP & Lenovo A6000 \\
\hline Layar & $\begin{array}{l}5.0 \text { inches, 720 x 1280 pixels } \\
\text { ( 294 ppi pixel density) }\end{array}$ \\
\hline Jenis layar & $\begin{array}{l}\text { IPS capacitive touchscreen, } \\
\text { 16M colors }\end{array}$ \\
\hline Internal & 8 GB storage, 1GB RAM \\
\hline O.S. & Android OS, v4.4.2 (KitKat) \\
\hline CPU & $\begin{array}{l}\text { Qualcomm MSM8916 } \\
\text { Snapdragon 410, Quad-core } \\
1.2 \text { GHz Cortex-A53 }\end{array}$ \\
\hline GPU & Adreno 306 \\
\hline Kamera belakang & $\begin{array}{l}8 \text { MP, 3264 x 2448 pixels, } \\
\text { autofocus, LED flash, Geo- } \\
\text { tagging, touch focus, face } \\
\text { detection, Video }\end{array}$ \\
\hline Kamera depan & 2MP \\
\hline Java & Yes, via Java MIDP emulator \\
\hline Baterai & Tipe Li-Ion 2300 mAh \\
\hline
\end{tabular}

\subsection{Desain Tampilan}

SCOTECT Mobile Apps terdiri dari beberapa tampilan, berikut merupakan beberapa hasil dari desain tampilan yang telah diimplementasikan.

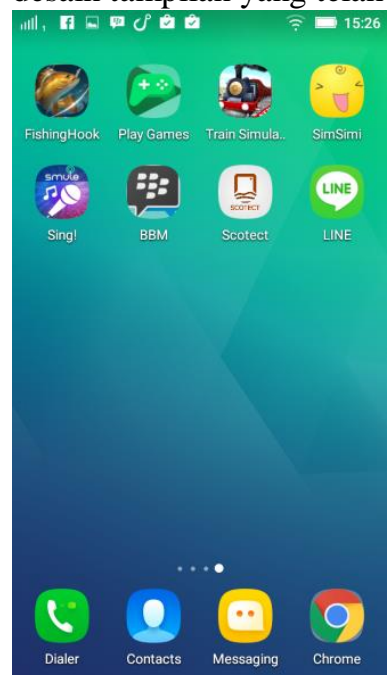

(a)

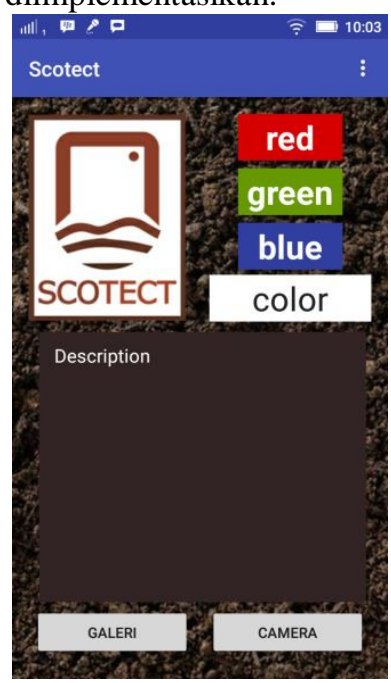

(b)
Gambar 2. (a) SCOTECT Mobile Apps pada perangkat (b) Tampilan SCOTECT Mobile Apps

\subsection{Pembuatan Database}

Database yang digunakan yaitu berupa gambar yang didapatkan dari buku Munsell Soil Color Chart. Dalam proses ini setiap citra digital warna dari buku Munsell Soil Color Chart akan diambil di crop untuk diambil nilai RGB-nya. Jumlah database terdiri dari 276 macam warna. Pengambilan database acuan diilustrasikan pada Gambar 3. 


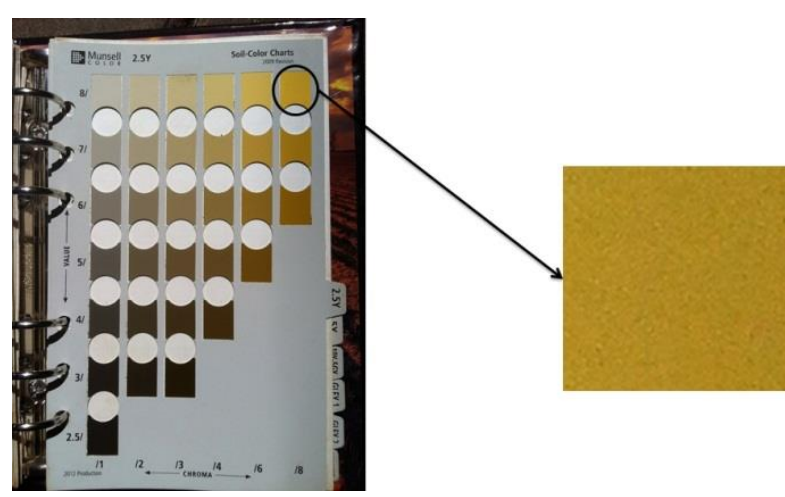

(a)

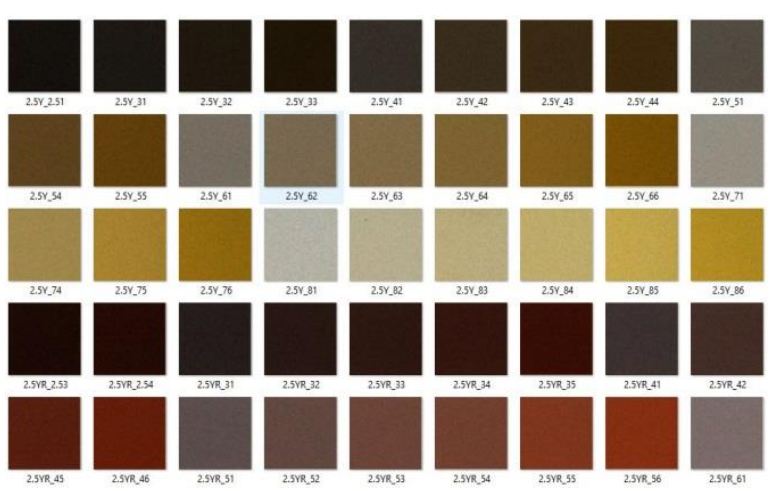

(b)

Gambar 3. (a) Proses crop Citra Digital (b) Contoh Database

Database terdiri dari 3 atribut, yaitu modus dari nilai R (merah), G (hijau), dan B (biru). Karena terdiri dari satu macam warna, modus merupakan representasi data yang paling sesuai untuk digunakan dalam aplikasi ini. Sesuai dengan ilustrasi yang ada pada Gambar 4 dibawah, Gambar 4(a) merupakan contoh dari warna tanah 10R 2.5/1 (hitam kemerahan) yang ada pada buku Munsell Soil Color Chart. Jika Gambar 4(b) merupakan nilai warna merah (R), Gambar 4(c) merupakan nilai warna hijau (G), dan Gambar 4(d) merupakan nilai warna biru (B) dari warna yang ada pada Gambar 4(a), dari himpunan nilai warna tersebut maka didapatkan nilai $\mathrm{R}=26, \mathrm{G}=18$, dan $\mathrm{B}=16$ sesuai dengan modus dari himpunan warna yang ada. Dari hasil pengambilan data menggunakan metode ini, didapatkan 276 data, contoh data yang ada dalam database ditampilkan dalam Tabel 3. Setiap label warna memberikan nilai yang berbeda bergantung pada kecenderungan warna yang dimiliki. Ada yang memilki kecenderungan warna merah, hijau, dan biru.

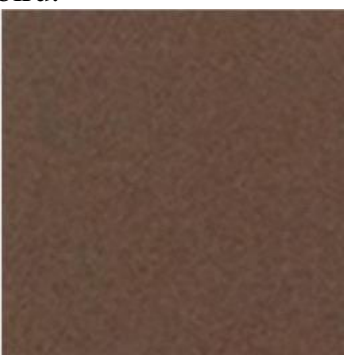

(a) $10 \mathrm{R} 2.5 / 1$

\begin{tabular}{|l|l|l|l|l|}
\hline 18 & 17 & 16 & 15 & 18 \\
\hline 14 & 18 & 18 & 18 & 18 \\
\hline 18 & 16 & 18 & 14 & 18 \\
\hline 18 & 18 & 17 & 18 & 17 \\
\hline 18 & 18 & 18 & 15 & 18 \\
\hline
\end{tabular}

(c) nilai warna hijau

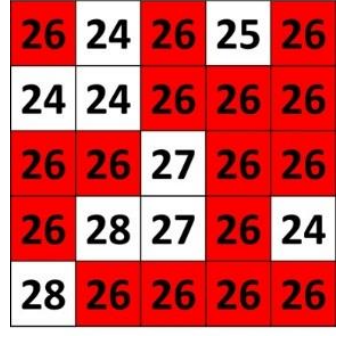

(b) nilai warna merah

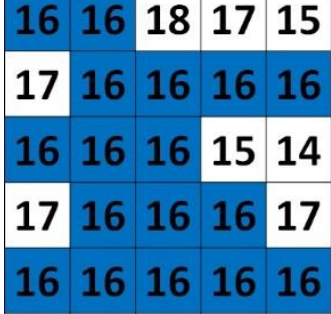

(d) nilai warna biru
Gambar 4. Cara Pengambilan Nilai Warna
Tabel 3. Contoh Database Warna Tanah

\begin{tabular}{clccc}
\hline No & Label Warna & R & G & B \\
\hline 1 & 10R $2.5 / 1$ & 26 & 18 & 16 \\
\hline 2 & 10R 2.5/2 & 30 & 16 & 14 \\
\hline 3 & 10R 3/1 & 36 & 28 & 28 \\
\hline 4 & 10R 3/2 & 44 & 26 & 24 \\
\hline 5 & 10R 3/3 & 46 & 22 & 18 \\
\hline 6 & 10R 3/4 & 49 & 20 & 14 \\
\hline 7 & 10R 3/6 & 55 & 11 & 6 \\
\hline 8 & 10R 4/1 & 59 & 48 & 49 \\
\hline 9 & 10R 4/2 & 69 & 45 & 40 \\
\hline 10 & 10R 4/3 & 76 & 42 & 35 \\
\hline
\end{tabular}

\subsection{Filterisasi Pertama}

Filterisasi ini dilakukan terhadap citra digital tanah yang ingin dideteksi warnanya. Dalam proses filterisasi pertama ini algoritma yang digunakan adalah Median Filtering Method. Dari hasil pengujian ketetanggaan, maka didapatkan nilai ketetanggaan yang sesuai adalah $15 \times 15$. Proses filterisasi warna akan menghasilkan citra digital dengan warna yang lebih seragam namun secara visual akan terlihat lebih kabur jika dibandingkan dengan gambar aslinya. Warna yang seragam ini akan membantu dalam proses segmentasi sehingga jika citra digital terdiri dari lebih satu lapisan batas setiap lapisan tanah akan lebih mudah ditemukan. Hasil dari proses filterisasi dapat dilihat pada Gambar 5.

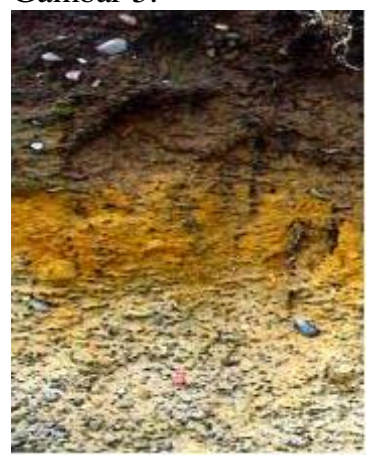

(a) gambar asli

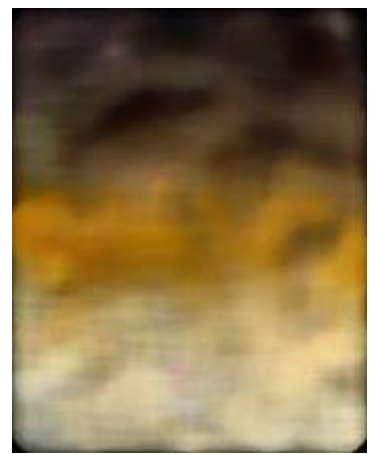

(b) filter $15 \times 15$
Gambar 5. Proses Filterisasi Pertama 


\subsection{Segmentasi}

Segmentasi dilakukan terhadap citra digital tanah hasil dari proses yang sebelumnya. Proses segmentasi dilakukan dengan menggunakan algoritma K-Means Segmentation Method. K-Means akan memisahkan setiap lapisan tanah jika citra digital terdiri dari lebih dari satu lapisan atau satu macam warna. Proses ini akan menghasilkan batas setiap lapisan tanah. Proses segmentasi ini sangat bergantung pada citra digital tanah yang dimiliki. Semakin mencolok perbedaan warna maka proses segmentasi akan semakin mudah dilakukan. Hasil dari proses segmentasi ditampilkan dalam Gambar 6. (a) gambar asli

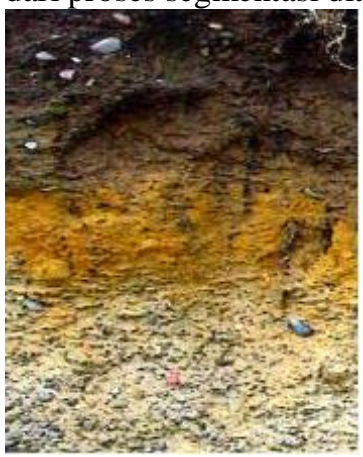

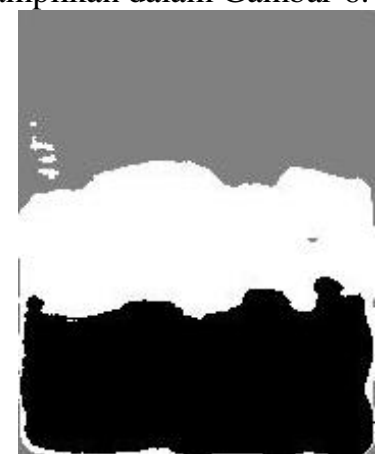

(b) hasil segmentasi
Gambar 6. Proses Segmentasi

\subsection{Filterisasi Kedua}

Citra digital kembali difilter menggunakan algoritma Median Filtering Method. Perbedaan dengan proses kedua, data masukan dalam proses ini merupakan citra digital hasil dari proses segmentasi. Ini dilakukan untuk menghilangkan derau yang masih ada dalam citra digital hasil segmentasi yang akan mengganggu dalam proses klasifikasi. Hasil filterisasi kedua ditampilkan dalam Gambar 7.

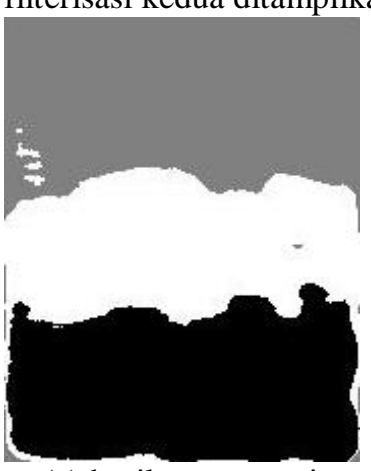

(a) hasil segmentasi

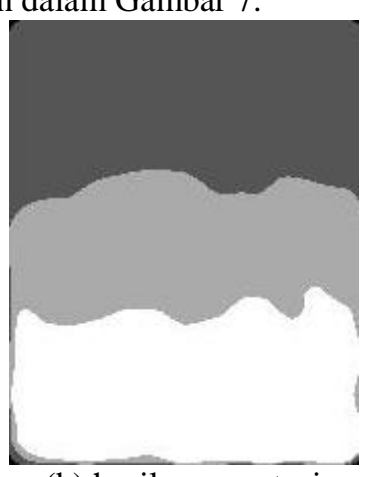

(b) hasil segmentasi
Gambar 7. Proses Filterisasi Kedua

\subsection{Klasifikasi}

Klasifikasi merupakan tujuan akhir dalam proses deteksi warna tanah. Tanah diproses dan diklasifikasikan ke dalam 276 warna tanah yang ada pada database. Dari proses ini akan didapatkan nama warna tanah dari citra digital tanah yang diproses pencarian warnanya. Pendekatan yang dilakukan adalah menggunakan Euclidean Distance yang akan menghitung nilai warna data masukan dengan nilai warna yang ada dalam database. Data yang nilai Euclidean Distance-nya dekat berarti data tersebut memiliki kemiripan, dan yang akan digunakan sebagai kesimpulan warna adalah yang nilai jaraknya terkecil. Dari penghitungan jarak yang dilakukan, didapatkan nilai jarak dari data uji dan data latih ada diantara 0 dan 12. Hasil pencocokan 276 data uji terhadap data latih, diketahui bahwa terdapat 26 data yang hasil klasifikasinya tidak sesuai, dan akurasi dari program yang dihasilkan mencapai 90,58\%. Tabel 4 menampilkan beberapa data hasil pengujian.

Tabel 4. Hasil Klasifikasi Warna

\begin{tabular}{cccr}
\hline No & Label Warna & Hasil Klasifikasi & Jarak \\
\hline 1 & 10R $2.5 / 1$ & 10R 2.5/1 & 1.7321 \\
\hline 2 & 10R 2.5/2 & 10R 2.5/2 & 1.0000 \\
\hline 3 & 10R 3/1 & 10R 3/1 & 0 \\
\hline 4 & 10R 3/2 & 10R 3/2 & 1.4142 \\
\hline 5 & 10R 3/3 & 10R 3/3 & 1.0000 \\
\hline 6 & 10R 3/4 & 10R 3/4 & 1.7321 \\
\hline 7 & 10R 3/6 & 10R 3/6 & 1.0000 \\
\hline 8 & 10R 4/1 & 2YR 4/1 & 0 \\
\hline 9 & 10R 4/2 & 10R 4/2 & 1.7321 \\
\hline 10 & 10R 4/3 & 10R 4/3 & 0 \\
\hline
\end{tabular}

\section{KESIMPULAN \& SARAN}

Penelitian ini berhasil memberikan alternatif dalam proses klasifikasi warna tanah. Penelitian ini dapat membuktikan bahwa SCOTECT Mobile Apps dapat digunakan dalam proses deteksi warna tanah dengan akurasi yang dihasilkan mencapai 90,58\% . Ada beberapa hal yang perlu diperhatikan dalam penelitian ini Pertama, aplikasi ini masih sangat bergantung pada citra digital yang digunakan, kualitas citra digital yang semakin buruk akan mempengaruhi hasil dari klasifikasi warna yang dilakukan. Kedua, aplikasi ini masih sangat lemah jika digunakan pada citra digital yang dihasilkan oleh perangkat yang berbeda, kedepan diharapkan akan ada penelitian tentang penggunaan aplikasi pada perangkat yang berbeda. Ketiga, perlu dipertimbangkan penentuan nilai ketetanggaan pada proses filter, karena ini sangat berpengaruh pada hasil.

\section{DAFTAR PUSTAKA}

ANAM, M.K., 2015. Pembuatan Alat Penentu Warna Tanah Berdasarkan Munsell Soil Color Charts. S.Kom Skripsi. Bogor: Institut Pertanian Bogor.

DEZA, M.M. \& DEZA, E., 2009. Encyclopedia of Distances. Berlin Heidelberg: Springer.

GONZALES, R.C. \& WOODS, R.E., 2012. Digital Image Processing. New Jersey: PrenticeHall, Inc. 
HAMERLY, G. \& ELKAN, C., 2002. Alternatives to the k-means algorithm that find better clusterings. In Conference on Information and Knowledge Management. Virginia, 2002.

HARDJOWIGENO, S., 1992. Ilmu Tanah. Jakarta: PT. Mediyatama Sarana Perkasa.

MUNIR, R., 2004. Pengolahan Citra Digital dengan Pendekatan Algoritmik. Bandung: Informatika.

MUNSEL, A.H., 2009. Munsell Soil Color Chart Book. Grand Rapids (US): X-Rite.

MURNI, A., 1992. Pengantar Pengolahan Citra. Surabaya: Elex Media Komputindo.

PATIDAR, P., GUPTA, M., SRIVASTAVA, S. \& NAGAWAT, A.K., 2010. Image Denoising by Various Filters for Different Noise. International Journal of Computer Applications, 9(4), pp.46-50.

PRIANDANA, K., S, A.Z. \& SUKARMAN, 2014. Mobile Munsell Soil Color Chart Berbasis Android Menggunakan Histogram Ruang Citra HVC dengan Klasifikasi KNN. Jurnal Ilmu Komputer Agri-Informatika, 3(2), pp.93-101.

PUSAT DATA DAN SISTEM INFORMASI PERTANIAN, 2013. Statistik Lahan Pertanian Tahun 2008-2012. [Online] Jakarta: Kementrian Pertanian Available at: http://pertanian.go.id/ [Accessed 24 September 2015].

PUTRA, D., 2010. Pengolahan Citra Digital. Yogyakarta: ANDI.

RAHMANI, K.I., PAL, N. \& ARORA, K., 2014. Clustering of Image Data Using K-Means and Fuzzy K-Means. International Journal of Advanced Computer Science and Applications, 5(7), pp.160-63.

UNITED STATES DEPARTMENT OF AGRICULTURE, 1999. Soil Taxonomy: A Basic System of Soil Classification for Making and Interpreting Soil Surveys. Washington DC: U.S. Government Printing Office.

UNITED STATES DEPARTMENT OF AGRICULTURE, 2000. The Color of Soil. [Online] Available at: http://www.nrcs.usda.gov [Accessed 21 Februari 2016].

WAHYUDI, 2012. Robot Hijau Masih Kuasai Indonesia. [Online] Available at: http://tekno.kompas.com [Accessed 20 Februari 2016].

YULIPRIYANTO, H., 2010. Biologi Tanah dan Strategi Pengolahannya. Yogyakarta: Graha Ilmu. 